\title{
Methodical Features of Foreign Language Teaching to Linguistically Gifted Students of Non-Linguistic Specialties: Foreign Experience
}

\author{
F. GALI Gulnara ${ }^{1}$, FAKHRUTDINOVA Anastasiya V. $^{2}$, \\ DULMUKHAMETOVA Gulnara F. ${ }^{3}$, GILYAZOVA Kamila R. ${ }^{4}$, GALI Askar I. ${ }^{5}$
}

\footnotetext{
${ }^{I}$ Kazan Federal University, Kazan, (RUSSIA)

${ }^{2}$ Kazan Federal University, Kazan, (RUSSIA)

${ }^{3}$ Kazan Federal University, Kazan, (RUSSIA)

${ }^{4}$ Kazan Federal University, Kazan, (RUSSIA)

${ }^{5}$ Kazan Federal University, Kazan, (RUSSIA)

Email: gulnaragali@mail.ru
}

\begin{abstract}
The relevance of the problem under investigation is caused by the fact that the issue of gifted students' education is one of the most difficult and interesting aspects of contemporary Russian and foreign pedagogy. Nowadays working with gifted students appears as an important and priority educational policy worldwide. The analysis of the research literature shows that the problem of talented students is constantly attracts the attention of educators and psychologists. The purpose of the article is to reveal conditions and factors, forms and methods of development of gifted students' abilities including linguistically gifted students of non-linguistic specialties. The article gives a detailed analysis of classroom work, extracurricular activities and independent forms of work. The author focuses on the specifics of working with gifted students, as well as on the analysis of foreign associations' activities, projects and programs. The leading approach to the study of this problem is a method of historical and logical analysis of regulatory documents of foreign governments and research papers of leading scientists dealing with gifted education issues. The main result of the study is the identification of the forms for the learning organization that promote creative achievements of linguistically gifted students. The materials of the article can be used in different researches and will be interesting for a wide range of readers dealing with the problems of teacher training for work with gifted students.
\end{abstract}

Keywords: education, gifted students, teacher, teaching foreign language, learning, foreign language competence, linguistic abilities, international educational experience

JEL: Z13

UDK: 371.3:81'243

159.928.23-057.875

\section{Introduction}

The problem of giftedness constantly attracts the attention of educators and psychologists in the modern world. The education and development of gifted students is one of the most urgent problems of modern pedagogics. Today, the problem of teaching gifted students is directly related to the new conditions and requirements of a rapidly changing world. The new information society exposes new challenges to the education system, since intellect and creativity have become the main productive and creative force of civilization. It is obvious that 
in modern conditions it is necessary to solve the problem of the content improving of gifted students' education, which is aimed at developing of the creative individuality of students and which has a number of differences from the content of education for the majority of their "normal" peers. According to the domestic researcher R. Sagitova, "we have to restructure the content of education to solve the problem of the individualization of learning, not in words, but in practice" [1].

It is important to note that the gifted students' teaching implies, first of all, scientifically based teachers' training who are ready to solve a whole range of issues related to this field. It should be noted that teachers face a problem while identifying students with outstanding intellectual abilities: what and how to teach, how to improve their optimal development.

Undoubtedly, the success of teaching and developing of gifted students requires the teacher to have his own concept of activities aimed at the intellectual and creative development of such students. Also, the specificity of the teacher's work, who educates gifted students, imposes higher requirements to him/her than to the ordinary teacher. In this regard, it is important to note the fact that there are some problematic points in the education of gifted students: the weakness of the scientific and methodological support of teachers working with this category of students, the unpreparedness of teachers for the individualization of teaching, the psychological and pedagogical support of gifted students, and also helping their parents [2].

The analysis of the scientific literature has shown that the goal of education for all students is to provide conditions for the disclosure and development of all abilities and talents to implement them in their professional activities. But with regard to gifted students, this goal is particularly significant. It should be emphasized that it is these students who will solve the urgent problems of modern civilization. Thus, to maintain and develop the individuality of a gifted student, not to lose it, not to slow down the growth of his/her abilities is a particularly important task of gifted students' teaching [3].

Thus, the work with gifted students and the problem of teachers' training is regarded as one of the most important problem worldwide. From this point of view the experience of foreign developed countries is interesting and useful (The USA, The UK, Germany, France, etc.). The analysis of foreign literature has shown that the main components of professional and personal competence of teachers to work with gifted students are professional teachers' training, professional and personal position, professional and personal qualities. Moreover, the relevance of the study of international experience is determined by the fact that it has not only theoretical but also practical significance and it deserves serious attention at the present stage [4].

To investigate this problem, the author used methods of historical and logical analysis of updated scientific sources.

\section{Methodological Framework}

The objects of the investigation are:

1. to identify the forms of learning organization of gifted students' education in foreign countries;

2. to determine the levels of foreign language competence;

3. to define the forms and methods of development of gifted students' abilities including linguistically gifted students of non-linguistic specialties;

4. to study the international experience of working with gifted students to enhance the effectiveness of gifted students' education in conditions of the national education system.

For confirmation of the hypothesis we need to turn into a variety of methods: 
- the method of historical and logical analysis of regulatory documents of foreign governments and research papers of leading scientists connected with educational issues of gifted students' education;

- study and theoretical analysis and synthesis of social, political and psycho-pedagogical literature;

- analysis, comparison, synthesis and generalization of innovative foreign and domestic pedagogical experience;

- comparison of data of foreign and domestic research on this issue.

The fundamental works of foreign and Russian scientists in the field of pedagogy and psychology (J. Frimen (1999), D. Parker (2011), J. Renzulli (1982), E. Torrens (1995), V.I. Andreev (2010), D.B. Bogoyavlenskaya (2002), N.S. Leytes (2004), A.M. Matyushkin (1988), V.I. Panov (2007), A.I. Savenkov (2004), F.L. Ratner (2009), etc.) were the theoretical basis of the study.

\section{Results}

\section{The Forms of Learning Organization of Gifted Students' Education in Foreign Countries}

The experience of the organization of gifted students' teaching in different countries has been analyzed. It should be noted that there is a great interest of different countries in innovative forms of work with gifted students. Many developed countries, such as the United States, Great Britain, Germany and others, carry out a large number of studies in the field of gifted education. Also there could be mentioned the activity of educational associations such as National Association for Gifted Children (NAGC, Washington, DC), American Association for Gifted Children (North Carolina at Chapel Hill), the Association of American Colleges and Universities (Washington, DC), Parent Teacher Association, the American Psychological Association (Washington, DC), the Educational Research and Information Center (ERIC) in the United States, the National Association for the promotion of gifted students in Education (NACE) in the UK and others.

These organizations deal with a variety of aspects of gifted students' training:

- providing affordable education and creating programs to help poor gifted and talented students;

- development of standards for educational programs for gifted and talented students, as well as their improvement;

- dissemination of information about the characteristics of the gifted, their needs for training at the level of their abilities, which is necessary for the realization of their potential;

- identification of problems in the field of gifted students' education and making these issues widely discussed at the national or regional level;

- providing assistance and support to the gifted, their parents, teachers, researchers;

- initiation and support of special projects for working with gifted students (Vainer, Gali \& Shakhnina, 2016).

Review and analysis of foreign literature have shown that national non-governmental associations that operate in almost all European countries play an important role in drawing the attention of governmental organizations and the general public. They are the initiators of the organization of special training programs for gifted students, training of pedagogical, psychological and administrative staff. They fulfill an independent expertise of the situation in gifted education and support different kinds of promoting innovation.

Theoretical analysis of foreign education reveals a highly developed system of gifted students' education, starting from kindergarten up to the system of higher education. 


\section{The Levels of Foreign Language Competence}

The interest of researchers in the study of foreign language competence is related to the transition of higher education from the qualification approach to the competency approach, with the reorientation of the educational result from the concepts of "knowledge/skills" to the concept "competence", with the transition from the qualification model of the specialist focused on the object and subject of work, to a competency-oriented specialist. The main conceptual ideas for using the competence approach in the process of professional training of future specialists are revealed in the works: V.I. Bidenko, A.A. Verbitsky (Bidenko, 2006; Verbitsky, 2009).

The analysis of the scientific literature on the research problem shows that the term "foreign language competence" is widely used with the synonymous term "foreign communicative competence". So, according to N.A. Proshyants, a foreign language competence is "the totality of sociocultural, linguistic knowledge, skills and abilities realized by the subject adequately to the communicative task in conditions of a foreign language environment. As a basic concept, foreign competence can be considered as a system of interacting elements, such as linguistic, linguocultural, sociocultural, professionally-foreign language, communicative competence" (Proshyants, 2010, pp. 34-35).

According to G.I. Bogin, N.I. Gez, the following levels of development of foreign language competence are distinguished, which reflect the linguistic components of the foreign language competence:

- the level of correctness (the ability of a person to use the available active vocabulary in combination with the correct application of elementary rules for word and form-usage of language units of a foreign language);

- the level of internalization (the communicant has a holistic view of the spoken expression);

- level of saturation (assumes a wide use of various language tools, the lack of primitive vocabulary and syntax);

- the level of adequate choice (confident possession of a variety of linguistic means in accordance with the context and with a specific situation);

- the level of adequate synthesis (reflects the development of a particular linguistic personality) (Bogin, 1984; Gez 1985).

J. Raven expanded this concept, including in its composition a number of components:

- linguistic (knowledge of vocabulary, phonetics, grammar and corresponding skills),

- sociolinguistic (reflects the socio-cultural conditions of language use),

- pragmatic (involves the implementation of the communicative function, the generation of speech acts) (Raven, 2002).

The analysis of scientific literature reveals that foreign language competence is considered by researchers as a complex, multicomponent education, with a professional orientation of foreign language competence of future specialists in the process of language training.

Speaking about the professional orientation of foreign language competence, it is necessary to highlight the components of foreign competence that determine the willingness and ability of the future specialist to solve typical problems and problems arising in professional situations with the use of knowledge of a foreign language:

- an operationally effective component (the ability to realize professional communication in a foreign language in the professional area);

- the cognitive component (professional (tasks and goals of professional activity, ways of professional self-education with the help of a foreign language) and linguistic 
(phonetics, vocabulary, grammar, geography) knowledge acquired during the study of a foreign language);

- the motivational-valuable component (the degree of representation of professionally significant motives and values to the study of a foreign language);

- reflexive component (ability of self-analysis, self-assessment in the process of foreignlanguage professionally oriented communication);

- emotional-volitional component (ability to self-regulation in the professional activity sphere and foreign professional communication, ability to overcome the psychological barrier in foreign-language communication) (Galustyan, 2008).

Thus, the foreign language competence of linguistically gifted students is such integrative personal and professional education that determines the ability and readiness of the student for a creative solution of practice-oriented and information-communicative tasks in the field of professional activity and foreign-language professionally oriented communication. According to V.M. Panfilova, the following structural components are distinguished:

- linguistic (knowledge of vocabulary, grammar, phonetics, orthography);

- discursive (ability of logical organization of speech and written texts);

- conversational (ability to speak coherently, without tension, at a natural pace, without long pauses to search for linguistic forms while receiving and transmitting professional information);

- pragmatic (the ability to convey communicative content in accordance with the social context);

- informational-technological (ability to search foreign-language professionally relevant information from various sources, to use productively foreign information resources in the process of professional activity);

- $\quad$ strategic (ability to use verbal and non-verbal professionally communicative strategies to compensate for missing knowledge in conditions of real language communication);

- sociocultural (knowledge of the socio-cultural context of the language used, the ability to build a foreign professional communication being adequate to these features);

- personal-creative (the ability to improve the level of foreign language skills, the ability to self- development in the process of independent creative activity) (Panfilova, 2015).

In this connection, it should be noted that nowadays foreign language teachers tend to use new approaches in the teaching of linguistically gifted students of non-linguistic specialties based on a communicative and personal-activity approach.

\section{The Forms and Methods of Learning Linguistically Gifted Students}

Speaking of linguistically gifted students, it should be noted that educational and professional foreign language activities aimed at the formation of foreign language competence of linguistically gifted students can be realized both in classroom and in extracurricular forms of education. The classroom work for linguistically gifted students includes active group-based forms of learning combined with individual research activities, such as projects, role-playing games, work with electronic dictionaries, work with Internet resources, work in phonolaboratories, presentations, competitions, quizzes, web quests, problem situations, discussions. Interactive forms allow us to organize active interaction of all participants of the educational process, exchange of authentic professionally important information in a foreign language and acquire skills of professional communication, during which improves the skills of unprepared speech, the ability to listen to the other opinion, to suggest solutions to the problem and develop instructions for new creative assignments (Fakhrutdinova \& Nurkhamitov, 2016). Integration of forms and methods of work leads to the simultaneous development of various types of speech activity: speaking, reading, writing and listening. This 
ensures the solution of communicative tasks of the use of grammatical and lexical forms, which makes it possible to master linguistic material and speech activity, and to develop various types of foreign language competence.

The most interesting tasks for linguistically gifted students are considered the method of "round table" and discussions, as these methods are a kind of dialogue, which includes the principle of collective discussion of the problem, the ability to combine elements of evidence and beliefs in the discussion. The student learns to express accurately his/her thoughts in the discussion, to defend actively his/her point of view in the reports and speeches, reasonably express or refute the opponent's erroneous position.

Extra-curricular forms of teaching that ensure the formation of foreign language competence are realized through creative and intellectual competitions and scientific-practical conferences.

Special attention should be paid to the organization of independent work of students that is an important condition in the process of forming foreign language competence of linguistically gifted students. The independent work of students is such educational and professional activities that are aimed at solving practical-oriented and research tasks for mastering foreign competence through the implementation of specific study assignments under the guidance of the teacher. The independent work of linguistically gifted students includes the following forms of work: creative and research projects, blitz surveys, essays, making presentations and reports on professionally-oriented topics in practical classes, educational Internet resources, participation in forums and electronic seminars, training projects.

Practice shows that the formation of foreign language competence of linguistically gifted students is largely determined by how to build the learning process, with the help of what forms and methods to involve students in educational and professional foreign-language activity. The content, forms and methods of work should provide an optimal educational space for active, free and creative self-development of linguistically gifted students, ensuring the variability and openness of the educational process, which allows the students the freedom to choose educational and professional foreign language activities.

\section{Conclusion}

In conclusion, it should be noted that many problems of teaching and developing gifted students are common for many countries and require close attention and interaction of the entire pedagogical community, personal growth of teachers, constantly updated knowledge in the field of gifted psychology and education. Considering the practical impossibility of involving of all students with actual and hidden talent for training under special programs, it is necessary to train teachers to work with gifted students in the conditions of the usual group.

This, in turn, assumes the teacher's knowledge of the principles of developmental learning, including the possession of special skills in applying differentiated programs for gifted students, as well as the possession of non-traditional forms and ways of working in the classroom. Having analyzed the works of domestic and foreign researches it can be concluded that the teaching of gifted students should be guided by a high level of abstract and problematic thinking, creative activity and taking into account the interests and hobbies of gifted students.

\section{Acknowledgement}

The work is performed according to the Russian Government Program of Competitive Growth of Kazan Federal University.

\section{REFERENCES}


1. Bidenko, V.I. (2006). Competence approach to the design of state educational standards for higher professional education (methodological issues): Methodological manual. Moscow: Research Center for Quality Problems in Training of Specialists.

2. Bogin, G.I. (1984). The model of linguistic personality in its relation to the varieties of texts (Doctoral dissertation). Leningrad.

3. Fakhrutdinova, A., Gali, G., \& Shakhnina, I. (2017). Pedagogical requirements for work with gifted students: teachers training approach. Proceedings of the INTED $2017-11^{\text {th }}$ International Technology, Education and Development Conference https://library.iated.org/publications/INTED2017.

4. Fakhrutdinova, A.V., \& Nurkhamitov, M.R. (2016). Technologies of interactive learning in higher education. International journal of Humanities and Cultural Studies; Special Volume, July 2016, 383389.

5. Galustyan, O.V. (2008). Pedagogical technology of monitoring of the formation of the foreign language communicative competence of students of a non-linguistic university (Doctoral dissertation). Voronezh.

6. Gez, N.I. (1985). Formation of communicative competence as an object of methodological research. Foreign languages at school., 2, pp. 17-23.

7. Korneva, I.G., Gali, G.F., \& Andreeva, E.A. (2017). Professional competence of teachers for working with gifted students. Alma Mater Vestnik of the Higher School, 12, pp. 50-54.

8. Panov, V.I. (2003). Giftedness as a pedagogical phenomenon. Supplementary education, 7, pp. 3-6.

9. Panfilova, V.M. (2015). Psychological and pedagogical conditions of the formation of foreign language competence of linguistically gifted students of a non-linguistic university (Doctoral dissertation). Yelabuga.

10. Proshyants, N.A. (2010). Formation of other linguistic competences in professional discourse. Research work, 3, pp. 34-38.

11. Raven, J. (2002). Competence in modern society: Identification, development and implementation. Translation from English. Moscow.

12. Sagitova, R.R., Nazmiyeva, E.I., \& Andreeva, E.A. (2017). Modeling of self-educational activity of university students in the process of teaching foreign languages using modern educational technologies. Vestnik NS BJD, 4 (34), pp. 54-59.

13. Vainer, E.S., Gali, G.F., \& Shakhnina, I.Z. (2016). Historic overview of gifted education in foreign countries. International Journal of Humanities and Cultural Studies (IJHCS). http://www.ijhcs.com/index.php/ijhcs/index.

14. Verbitsky, A.A., \& Larionov, O.G. (2009). Personality and competence approaches in education: problems of integration. Moscow: The Logos.

\section{Article history: \\ - $\quad$ Received 30 August 2019 \\ - Accepted 14 November 2019}

